\title{
Influence of on-farm liquid organic manures on soil health and crop production
}

Sreya U. Parvathi and K. Ushakumari

Received : 02.04.2020; Revised : 02.05.2020; Accepted : 19.05.2020

MEMBERS OF RESEARCH FORUM:
Corresponding author :
Sreya U. Parvathi, Department of
Soil Science and Agricultural
Chemistry, College of Agriculture,
Vellayani, Thiruvananthapuram
(Kerala)India
Email: sreyasoil@gmail.com

Co-authors :

K. Ushakumari, Department of Soil Science and Agricultural Chemistry, College of Agriculture, Vellayani, Thiruvananthapuram (Kerala) India

\section{Summary}

A study on "Influence of on-farm liquid organic manures on soil health and crop production" was undertaken at the College of Agriculture, Vellayani during 2014-2017. The experiment was to evaluate the efficacy of soil and foliar applications of on-farm liquid organic manures on soil health and crop nutrition using Okra as a test crop. The treatments included were 75 per cent $\mathrm{N}$ as enriched vermicompost along with diluted liquid organic manures separately as soil and foliar applications. The post-harvest analysis of soil revealed that $\mathrm{pH}, \mathrm{EC}$, organic carbon and labile carbon contents varied significantly among the treatments. The highest organic carbon content of the soil was recorded by $\mathrm{T}_{4}$ and $\mathrm{T}_{12}$. The maximum labile carbon was recorded by $\mathrm{T}_{8} . \mathrm{T}_{5}$ was rich in available $\mathrm{N} \mathrm{T}_{5}$ registered the highest plant uptake of major nutrients. The treatment $\mathrm{T}_{3}$ registered the highest plant uptake of secondary nutrients. The highest value of $\mathrm{Fe}$ and $\mathrm{Zn}$ uptake was noticed in $\mathrm{T}_{11}$. The highest value of $\mathrm{Cu}$ uptake was noticed in $\mathrm{T}_{1}$. The highest value of Mn uptake was noticed in $\mathrm{T}_{3}$. The lowest plant uptake of all nutrients was recorded by $\mathrm{T}_{13}$ (Absolute control). Economics of cultivation of okra indicated that the cost-benefit ratio was found higher for treatment $\mathrm{T}_{5}, 75$ per cent $\mathrm{N}$ as $\mathrm{EVC}+$ Panchagavya 3 per cent foliar application (2.83) followed by $\mathrm{T}_{7,} 75$ per cent $\mathrm{N}$ as $\mathrm{EVC}+$ cow urine 10 per cent foliar spray (2.09).

Key words : Okra, Benefit-cost ratio, Enriched vermicompost, Liquid organic manures, Growth, Yield attributes, Nutrient uptake, Soil health

How to cite this article : Parvathi, Sreya U. and Ushakumari, K. (2020). Influence of on-farm liquid organic manures on soil health and crop production. Asian J. Soil Sci., 15 (1) : 11-21 : DOI : 10.15740/ HAS/AJSS/15.1/11-21. Copyright@ 2020: Hind Agri-Horticultural Society. 